\title{
Du Boisian Propaganda, Foucauldian Genealogy, and Antiracism in STS Research
}

\author{
ANTHONY RYAN HATCH \\ WESLEYAN UNIVERSITY
}

\begin{abstract}
This essay explores the relationships between the "new" anti-science formation under Trump and the kinds of anti-Black racisms we are experiencing at present. What appears at first glance to be a new anti-science formation, isn't new at all, but old wine in new cloth, all dressed up to confound and distract our gaze from power. The vast majority of Black and Brown people are not surprised nor fooled by Donald Trump and the danger he represents to truth, to our lives, to our precious Earth. For that matter, how are STS scholars working to produce anti-racist knowledge that directly benefits Black people? In this commentary, I briefly respond to these questions by exploring how wildly contrasting accounts of propaganda, truth, and science by W.E.B. Du Bois and Michel Foucault might help STS scholars make sense of the relationship between anti-Black racism and the current anti-science moment in American society.
\end{abstract}

\section{Keywords}

Du Bois; Foucault; propaganda; genealogy; science; anti-black racism

In March 2019, I joined several brilliant sociologists of science to discuss how STS and science more generally is faring in the current era of anti-science under the terrible regime of the first Trump administration. The prompt signaled to me that there was something distinctive about this moment as it is being articulated through the totalitarian tendencies of Trump himself, the coordinated production of corporate, state, and scientific propaganda, and monstrous configurations of injustice and inequality around the world. The Trumpian moment is a horrifying and monstrous moment, especially for non-white folx who seem to represent an existential threat to the version of white supremacy ascendant in 2019. No doubt, I'd like to see it pass sooner than latter. But, was this moment really new? I know that moments like this cast a long shadow over our collective tomorrows, and, it is absolutely essential to remember that moments like this also have a history. Trump's racist America has always been here, braided into the very being of this ostensibly great nation.

I wanted to think about the relationships between this "new" anti-science formation under Trump and the kinds of anti-Black racisms we are experiencing at present. I have two questions in mind. First, is this moment continuous or discontinuous with America's history vis-

. Anthony Ryan Hatch, Email: ahatch@wesleyan.edu

Copyright (c) 2020 (Anthony Ryan Hatch). Licensed under the Creative Commons Attribution Non-commercial No Derivatives (by-nc-nd). Available at estsjournal.org. 
à-vis Black people? My answer is that we are experiencing what Patricia Hill Collins called "the changing same" with respect to anti-sciences and racism (Collins 2010). Things change and yet they stay the same. What appears at first glance to be a new anti-science formation, isn't new at all, but old wine in new cloth, all dressed up to confound and distract our gaze from power. The vast majority of Black and Brown people are not surprised nor fooled by Donald Trump and the danger he represents to truth, to our lives, to our precious Earth. We've seen so many of his kind in that office before (hint: Trump's favorite people Robert E. Lee, Andrew Jackson, and Ronald "The Monkey" Reagan). We know that this is what it means to live as a Black subject in these United States and we know what its like to be lied to.

This brings me to my second question: what is the relationship between Black people and STS? I'm not sure there's much of a relationship to speak of with the exception of a few pioneering scholars who are developing those actual social and scientific relationships with Black communities (Benjamin 2013). How are STS scholars working to produce anti-racist knowledge that directly benefits Black people? In this commentary, I briefly respond to these questions by exploring how wildly contrasting accounts of propaganda, truth, and science might help STS scholars make sense of the relationship between anti-Black racism and the current anti-science moment in American society.

Let's start with racism, something STS scholars might want to pay closer attention to for all sorts of beautiful, life-affirming and scientifically justifiable reasons. Racism is a one-two combination punch. The first punch is the raw physical and psychic death-dealing violence that has had White people shooting, raping, beating, bombing, mutilating, extracting, and otherwise forcing themselves onto non-white folx in clear patterns linked to race, gender, sexuality, age, disability, social class, and nationality. This is racial necropolitics, as articulated through the institutional effects of a violent infrastructure war that kills people of color in systematic and certain fashion (Mbembé 2003).

The second punch is the vast production and dissemination of propaganda that stuns the consciousness and lies about the truth of the violence just experienced in the first punch. The second hit is all of the lies that white supremacy has to tell to cover its tracks. It tries to explain the pain, suffering, and abjection away as the effect of "racial," natural, biological and evolutionary forces that have absolutely nothing to do with one group's enactment of violence on others. This is racial biopolitics, as expressed through the production of purportedly scientific knowledges about life, health, and population and the integration of these knowledges into capitalist economies and liberal modes of government (Foucault 1976). All sorts of political forces act on institutions that produce knowledge and the processes that establish scientific facts about race and racism.

This racial science is what philosopher Jason Stanley calls "false ideology," which forms part of the cultural framework through which people interpret information about the world (Stanley 2015: 38). If propaganda is the production and dissemination of false and/or misleading information as a political strategy, many of the sciences of racial difference would seem to qualify as propaganda. The epistemic function of racist scientific practices is to justify, explain away, support, and enable the facts of racial domination, while at the same time, such practices often 
enact their own material harm on the raced body independently of the effects they are allegedly measuring in the first place. One enshrined as the definitive explanations for (the) history (of race), these forms of propaganda do real harm. Cultural theorist Stuart Hall understood this in his critique of how colonial violence has to be forgotten in order for the principle of national unity to emerge in settler states (Hall 1996), as did Historian Howard Zinn through his invective that authoritative history is, all too often, told from the perspective of states, thieves, and killers (Zinn 2015). Scholars working at the intersection of critical race theory, science and technology studies, and history of science have recently accelerated their analysis and critique of these specific forms of propaganda as they emerge specifically through science, medicine, and health (For excellent examples of this kind of work, readers should consult Lundy Braun's Breathing Race into the Machine (Braun 2014), Ruha Benjamin's Race After Technology (Benjamin 2019), Rana Hogarth's Medicalizing Blackness (Hogarth 2017), and Catherine Bliss's Race Decoded (Bliss 2012). My own work grapples with many of these questions, too (Hatch 2016 and Hatch 2019). There are many, many other contemporary scholars to mention here, but I'd like to turn back to what I believe is the first sociology of knowledge analysis authored in the United States: The concluding chapter of W.E.B. DuBois' 1935 masterpiece Black Reconstruction in America: 1860-1880 titled "The Propaganda of History" (Du Bois 1935).

It is my favorite single piece of critical sociological theory; I commend it to anyone who claims the title of scientist, historian, investigator. The chapter begins as did every other chapter in this volume, with a synopsis:

How the facts of American history have in the last half century been falsified because the nation was ashamed. The South was ashamed because it fought to perpetuate human slavery. The North was ashamed because it had to call in the black men to save the Union, abolish slavery, and establish democracy.

Du Bois offers two interpretations of propaganda, one that interrogates racist practices and the other that promotes anti-racism. For the first, DuBois systematically chronicles the omissions, distortions and outright lies the nation's white historians told about the role of the so-called Negro in the failure of American Reconstruction. If we were to believe the major white historians of the time, or what was written in American school textbooks, we would blame the failure of Reconstruction on the the ignorant and lazy Negro for his incapacity for good government. White supremacist histories would have us believing that white people and the institutions they set up had nothing to do with the failure of the nation to heal after the Civil War. "It is propaganda like this," Du Bois chides, "that has led men in the past to insist that history is 'lies agreed upon'" (Du Bois 1935: 714).

He traces the individual biographies of Reconstruction's leading white historians and situates them in the context of the broader systems of propaganda production. Never one to mince words, Du Bois castigated many of the leading white historians of Reconstruction for their abrogation of their solemn responsibility to tell the truth instead offering a defense of the white race that frees them from moral culpability in slavery, the Civil War, or its aftermath. He spares no one, targeting the major historians and schools of historical thought, major publishing houses, 
even the Encyclopedia Britannica, in his quest to demonstrate how these actors and institutions participated in the production and dissemination of white supremacist propaganda designed to elevate and calm a tired and broken white population and denigrate and erase the Negro.

At the epistemological heart of Du Bois' argument is his progressive view that if we approached writing history as a scientific practice, a practice that focused on "distinguishing between fact and desire," we might be able to "use human experience for the guidance of mankind" (Du Bois 1935: 722). If historians distorted the facts of history "to make pleasant reading for Americans," that false history would be a useless or even dangerous guide. As Du Bois suggests here, the danger of this propaganda is that it stands in as authoritative history, authored by people who clearly benefitted financially and politically from that authoritative history and the violence it covers up. Importantly, Du Bois viewed the documentation of "things that actually happened" as distinct from the analytic work of interpreting the meaning of those facts. Here, he expounds on this key distinction:

\begin{abstract}
Someone in each era must make clear the facts with utter disregard to his own wish and desire and belief. What we have got to know, so far as possible, are the things that actually happened in the world. Then with that much clear and open to every reader, the philosopher and prophet has a chance to interpret those facts; but the historian has no right, posing as a scientist, to conceal or distort facts; and until we distinguish between these two functions of the chronicler of human action, we are going to render it easy for a muddled world out of sheer ignorance to make the same mistakes ten times over (Du Bois 1935: 722).
\end{abstract}

If the "chronicler of human action" does not properly interpret the facts before them in their proper context, their versions of history and truth will be utterly distorted and contribute to the mass production of ignorance and the reproduction of anti-black racism. Du Bois fights against white supremacy and scientific racism by using some of the tools of Western science-empirical analysis and positivism - to fight against a racist discourse (in this case, the discipline of history) that claims to be, but is not, a science.

$\mathrm{Du}$ Bois really believed in the promise of science and Truth for Black people, both in terms of how they would force Whites to see themselves and their actions in the clear light of day and how they would help Black people to cultivate true self-consciousness and liberation. Du Bois also offers us an anti-racist interpretation of propaganda that can and should be produced and distributed widely to help Black people achieve liberation. This meaning of propaganda is connected to old religious traditions that aimed at spiritual and emotional conversion of people through the use of rhetoric and storytelling. Du Bois' decided to include Biblical references, hymns, music, and poetry in his published works, in part, to manipulate both White and Black people's deepest feelings about Black people. If scholars and artists could convince White people of the inherent humanity of Black people (counter to what white supremacy says about the inherent inhumanity of Black people), White people would begin to treat Black people like humans. 
Du Bois' approach to questions of truth, science, and history strikes me as strangely resonant with Michel Foucault's approach to genealogy. While they are not often discussed together, Du Bois and Michel Foucault are both fighting against discourses that claim to be scientific, but take very different approaches to epistemology. Du Bois believed in and tried to produce science and Truth. Foucault denies the possibility of any science to produce truth, and understands the sciences as fields of knowledge arrayed across and deeply connected to networks of institutional power. I don't think Foucault believed in science and I know that he was not interested in producing science or in being a scientist. But, I think Foucault was interested in producing an "anti-science" that could fight against any discourse that people claimed was a science. Isn't this what Michel Foucault's methodology of genealogy is supposed to do?

Genealogies are anti-sciences that fight against the material and epistemological effects of supposedly true discourses. For my first book Blood Sugar: Racial Pharmacology and Food Justice in Black America and the dissertation that informed it, at the explicit direction of my dissertation advisor, I spent months figuring out what it would look like to use genealogy as a research methodology and what it might mean to embrace Foucault's view of truth, science, and history in my analysis of race and metabolic syndrome (Hatch 2016: 11-14). My understanding is that genealogies document how a purportedly true discourse (whether it be scientific or legal or religious) is inserted into power relationships that govern the body and regulate the broader social order. By showing this, genealogies work as political interventions that aim to disrupt the close association of the production of knowledge and practices of government (or, knowledge and power) in a given society. In my work, I traced how the emergence of supposedly true discourse about what was called "metabolic syndrome" were inserted into racial projects in the US racial state and biomedical capitalism that targeted and intervened on the metabolic health of Black people and other groups.

While I did not explicitly draw on Du Bois' theorizations about racist propaganda in Blood Sugar, I was drawing on critiques of racist discourses from critical race theories that were themselves shaped by Du Boisian thinking. Just as white historians tried to blame the failure of Reconstruction on the ignorance, laziness, immorality, and incivility of Black people, metabolic syndrome researchers were trying to blame extreme racial disparities in health on the inferior biologies, lack of individual responsibility, and unhealthy cultures of Black people. Du Bois believed that analysts should try to use the tools of empirical social science to craft new racially honest knowledges that disprove the propagandist lies told by white supremacy.

And, this is where Du Bois and Foucault part ways. Du Bois believed in the capacity of an honest science to tell the truth of history, a truth that had liberatory potential. Du Bois was able to critique the historians who produced the propaganda by challenging their claims with new counter-claims. Foucault argued for an anti-science that would expose how power is inextricably linked to the truth of history and every other possible knowledge. Genealogists should not try to establish a new alternative knowledge that competes with the false, dominant one, but should combat the political institutions that allow a scientist to claim to be producing truth in the first place. 
Bridging these two perspectives, I was not trying to posit any new scientific hypotheses about metabolic syndrome, racial difference, and Black people. I was contesting metabolic syndrome scientists' ability to make such claims by exposing their social positions and political interests as they authored knowledge. The people who authored metabolic syndrome discourses were my primary audience, and I suppose that I was trying to get them to pay attention to the racial discourses they were producing, many of which relied on scientific racism and American individualism for meaning.

Because many of these racial discourses about metabolic syndrome were produced in the idiom of colorblind racism, their racism is hard to see. Moreover, this kind of knowledge is a big social problem because it makes it difficult for everyday people, especially Black people, to understand why they have the health challenges that they do (Williams and Mohammed 2013). They are likely to misunderstand the complex biosocial processes that cause disease and health inequalities. Especially dangerous also were the causal discourses that tried to link race and metabolic syndrome across biomedical specialties and fields of knowledge, like the discourses about why there were racial differences in food and drug metabolism. These are scientific claims and practices that have real clinical significance in people's daily lives and impact whether and how we confront the fundamental causes of disease in American society (Link and Phelan 1995).

When I share these ideas from Blood Sugar with non-academic folx, I always field more questions from everyday Black people that are about their personal struggles or family members' challenges with diabetes, heart disease, and obesity-the metabolic disorders that comprise metabolic syndrome. They didn't want to talk about genealogy. They didn't really want to talk about how the metabolic syndrome fit into the long, sad history of scientific racism. Foucault's genealogy didn't offer me a way to produce knowledge that was useful in these moments. My Foucauldian genealogy only resonated within scholarly communities, and really only with some of them (mostly the STS people). Perhaps a more explicitly Du Boisian approach would have been more helpful in offering a new alternative truth, one that my non-academic readers/listeners could use to govern their bodies differently within the strictures of white supremacy as it manifests itself in the embodied phenomena of the metabolic syndrome itself.

If STS scholars want to win the propaganda war against racism (if winning such a conflict is even possible), if they want to help Black and Brown people defend against the onetwo punch of racism, they should grapple with the politics of knowledge that define the science they make, the kinds of stories they tell about the world, and how the people impacted by that science understand the work they are so committed to producing. I have come to embrace a kind of intersectional perspectivism that recognizes the social and political situatedness of social groups claims to speak, write, and "discover" truth and the significance of lived experience for understanding that embodiment (Collins 1999; Scott 1991). My work grapples with the politics of knowledge and tries to document the sites of knowledge production with some sense of empirical rigor (Duster 1990). But, I also have had to recognize how important it is for the everyday people I claim to write for to hear something truthful from me. I have to be a truth teller, or at least, I have to cultivate confidence that the interpretations I'm making about social and scientific worlds have some basis in what actually happened. As Patricia Hill Collins 
reminded us back in 1998, poststructuralist and postmodern theories of knowledge became all the rage just as Black women began to enter the academy in serious numbers (Collins 1998). All of a sudden, truth is no longer possible, just as Black people grab the pen and mic to fight for justice and liberation.

\section{Author Biography}

Anthony Ryan Hatch, PhD, is Associate Professor and Chair of Science in Society Program at Wesleyan University.

\section{Acknowledgements}

I would like to acknowledge and thank Laurel Smith-Doerr for the invitation to participate in the Presidential Panel on Science and Technology Studies in an Era of Anti-Science I: Perspectives on Science and Politics at the Eastern Sociological Society Annual Meeting in March 2019. I would also like to thank Daniel Kleinman and Katie Vann for their editorial work on this essay and the commenters who generously engaged with these ideas.

\section{References}

Benjmain, Ruha. People's Science: Bodies and Rights on the Stem Cell Frontier. Palo Alto: Stanford University Press, 2013.

Benjamin, Ruha. Race After Technology: Abolitionist Tools for the New Jim Crow. Cambridge: Polity, 2019.

Braun, Lundy. Breathing Race Into the Machine: The Surprising Career of the Spirometer from Plantation to Genetics. Minneapolis: University of Minnesota Press, 2014.

Collins, Patricia Hill. Fighting Words: Black Women and the Search for Justice. Minneapolis: University of Minnesota Press, 1998.

Collins, Patricia Hill. 2010. "The new politics of community." American Sociological Review 75 (1): 7-30.

Du Bois, W.E.B. Black Reconstruction in America, 1860-1880. New York: Free Press, 1998 [1935].

Duster, Troy. Backdoor to Eugenics. Routledge, 2004.

Foucault, Michel, and François Ewald. "Society Must Be Defended": Lectures at the Collège de France, 1975-1976. Macmillan, 2003.

Hall, Stuart, and Paul Du Gay, eds. Questions of Cultural Identity. New York: Sage Publications, 1996.

Hatch, Anthony Ryan. Blood Sugar: Racial Pharmacology and Food Justice in Black America. Minneapolis: University of Minnesota Press, 2016.

Hatch, Anthony Ryan. Silent Cells: The Secret Drugging of Captive America. 
Minneapolis: University of Minnesota Press, 2019.

Link, Bruce G., and Jo Phelan. 1995. "Social conditions as fundamental causes of disease." Journal of health and social behavior: 80-94.

Mbembé, Achille and Libby Meintjes. 2003. "Necropolitics." Public Culture 15 (1): 11-40.

Scott, Joan W. "The evidence of experience." Critical Inquiry 17, no. 4 (1991): 773-797.

Stanley, Jason. How Propaganda Works. Princeton: Princeton University Press, 2015.

Williams, David R., and Selina A. Mohammed. "Racism and health I: Pathways and scientific evidence." American Behavioral Scientist 57, no. 8 (2013): 1152-1173.

Zinn, Howard. 2015. A people's history of the United States: 1492-present. New York: Routledge, 2015 [1980]. 